\title{
日. 本農藝化學會誌
}

第 13 管第 12 呵第 159 號 昭和 12 年 12 月

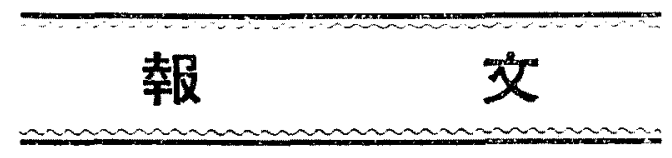

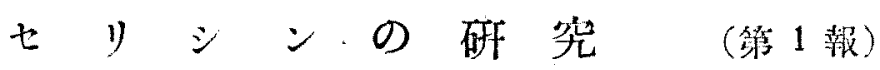

渵愿よりセリシン抽出に際しアムモニアの生成に就て

伊藤 武男, 小菻膜三

（京都高等䈱總學校化學教室）

炤和 12 年 9 月 25 日受理

七リシンは少くとも二種のフラクションより成り，而して夫等は相互に性状を異にするが故

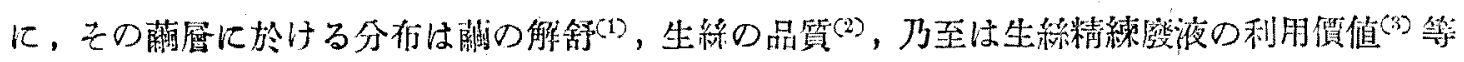

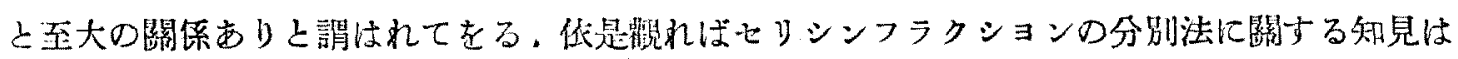
製絲化學上重要なる意義を有する理である。之に就ては巳に諸家の厘次砄究發表せるものがあ

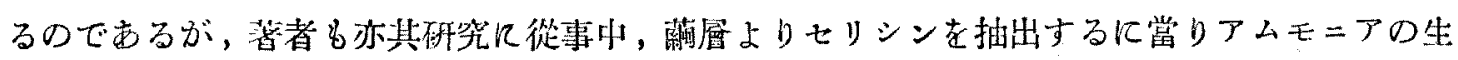

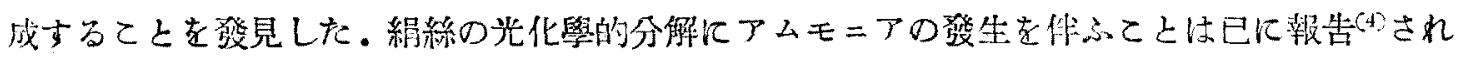
てをるが，其以外には斯る事は未だ知られてをら好やうである。

\section{實 驗 の 部}

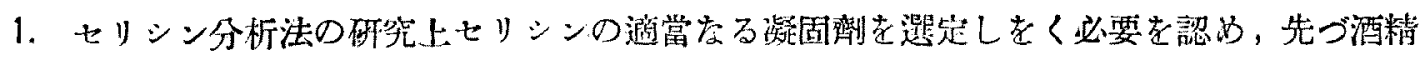
に就て下記の質驗を陚みた：一

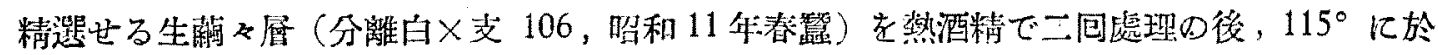

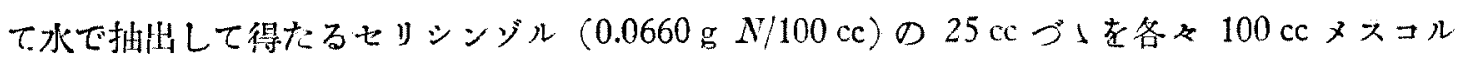

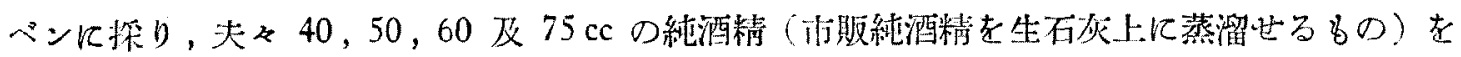

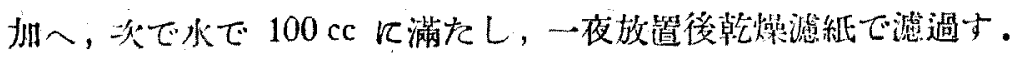

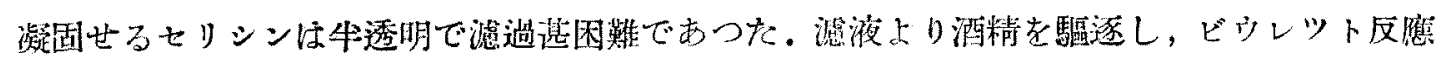

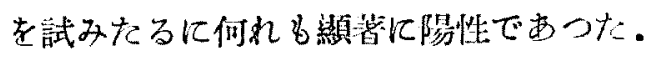

即ち、七リシンは75\%酒精老以てしても完全には凝固されない。これは七リシンミセルの荷 䉓に因る叮きが故に，少量の多傾イオンを涯㻚すれば酒精凝固を完全をらしめ得るであらう。

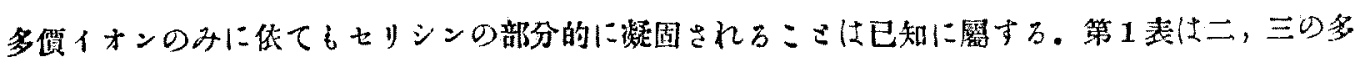

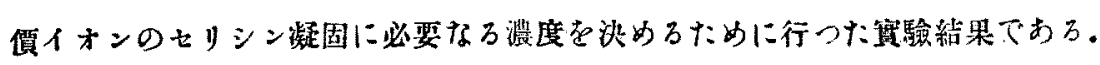


第1裴セリシンの多儥イオンによる凝固.

セリシン滥度： $0.0026 \mathrm{~g} \mathrm{~N} / 10 \mathrm{cc}$

\begin{tabular}{|c|c|c|c|c|c|c|c|c|c|}
\hline 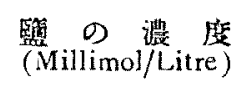 & 0.02 & 0.05 & 0.1 & 0.15 & 0.2 & 0.4 & 0.8 & 1.6 & 3.6 \\
\hline $\mathrm{MgSO}_{4}$ & & & & & - & - & - & + & + \\
\hline $\begin{array}{l}\mathrm{CuSO}_{4} \\
\text { 加里明禁 }\end{array}$ & \pm & $\begin{array}{l}- \\
\pm\end{array}$ & + & - & + & $\begin{array}{l}+ \\
+\end{array}$ & $\begin{array}{l}+ \\
+\end{array}$ & + & + \\
\hline
\end{tabular}

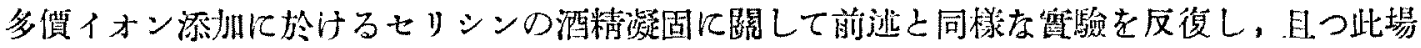
合には㴓液中の $\mathrm{N}$ をb定量した。凝固セリシンの滤過は前述の場合に比較して著しく容易で あった。

第 2 表 多瞥イオン源加に於けるせリシンの酒精凝固.

（滤液中 $\mathrm{N}$ の全 $\mathrm{N}$ 亿璟する\%）

\begin{tabular}{|c|c|c|c|}
\hline 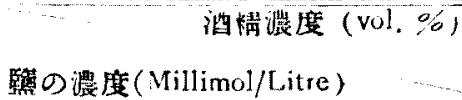 & 50 & 60 & 75 \\
\hline $\mathrm{MgSO}_{4} \quad 2$ & $4.9(+)$ & $3.3(t)$ & $2.1 \quad(-)$ \\
\hline $\mathrm{CuSO}_{4} \quad 1$ & $2.6 \quad(-)$ & $2.2(-)$ & $1.6(-)$ \\
\hline 加里明禁 0.1 & $2.8 \quad(-)$ & $1.8(-)$ & $1.6(-)$ \\
\hline
\end{tabular}

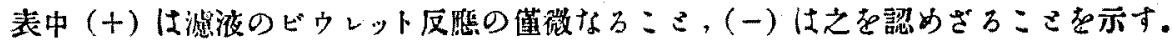

表に㨡り，少量の多價イオンの存在に於てはセリシンは酒精に体て完全に凝固せらるつこと 及び全 N の約 $1.6 \%$ に相當する非蛋白態窒素化合物が供試セりシンジルに含まれてをることが 判る。

2. 前逃上同栐にして調製せるセリシンジル $50 \mathrm{cc}$ よりセリシンを酒棈で凝固せしめ，其滤

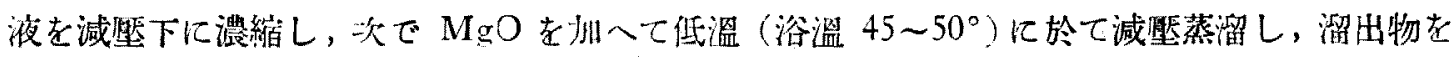

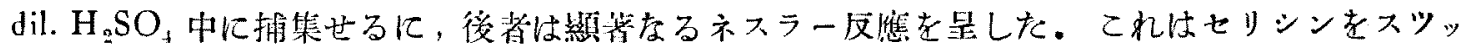

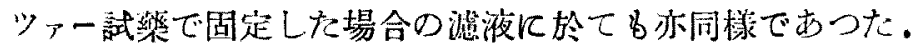

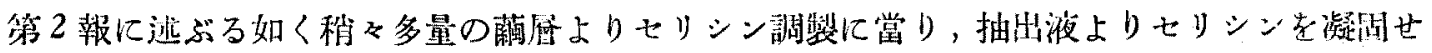

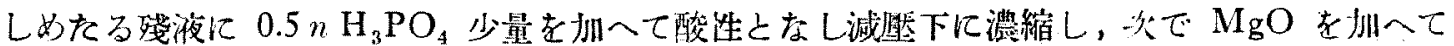

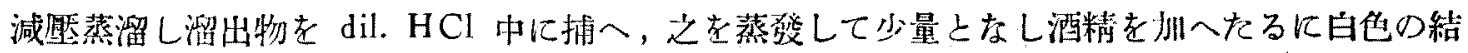
晶を析出した。滤別して之を少量の水に浚かしたる溶液は次の反應索與へた：-

(1) Francois' reagent ${ }^{(5)}$ を加ふれば冷時褐色沈澱を生ず。

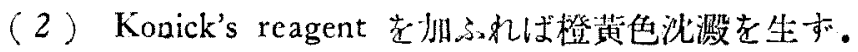

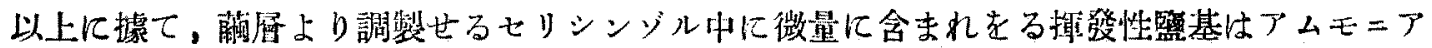
と推定せられる。䆙量的證明は之を後日に期することつする。

このアムモニアの由來を檢するために次の望驗を行つた：- 


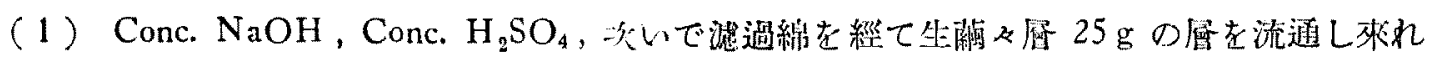

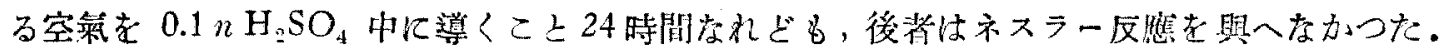

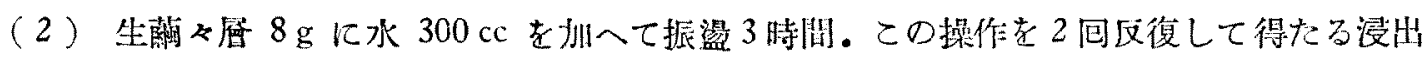

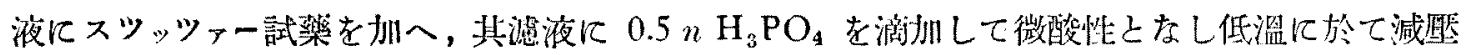

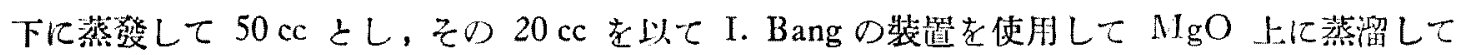
アムモニアを半ミクロ的に定量した。

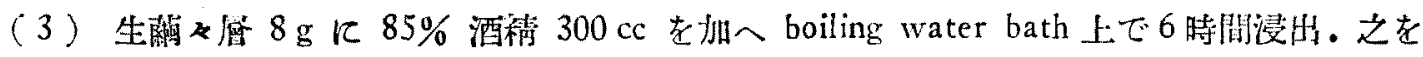
2 包反復し，最後に冷酒精にて上く洗源し，浸出液中のアムモ=アを(2) 上同㥞にして定量し た。向，茲に使用せる酒精は少量の硫酸，炊いで生石扊を州へて蒸溜し，最後に向一包蒸溜し て精製せるものである。

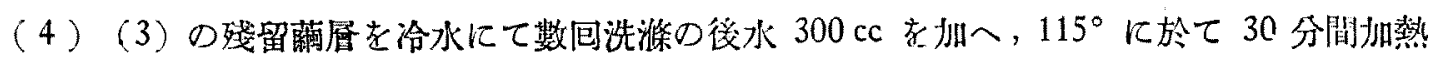

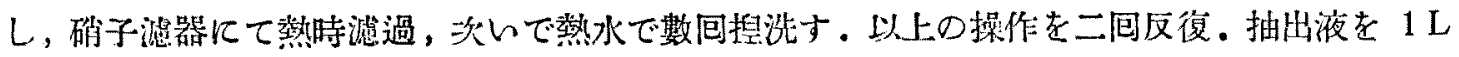
とし，その $200 \mathrm{cc}$ 中のアムモニアを䇥量した。

以上の實驗結果を姴錄して次の第 3 裴老得を。

\begin{tabular}{|c|c|c|c|}
\hline No. & 酸 層處理の方法 & 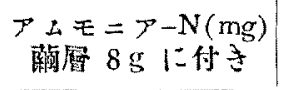 & ネスラー反㫿 \\
\hline 1 & 空氣々流に依て排除 & 0.00 & 認めす \\
\hline 2 & 冷水教加一一振海 3 時間，2回 & 0.09 & 極嚾微 \\
\hline 3 & $\begin{array}{l}\text { Boiling water bath 上で } 85 \% \text { ó 酒精にて } \\
\text { 浸出 } 6 \text { 時間，2间 }\end{array}$ & 0.92 & 䕐 藷 \\
\hline 4 & 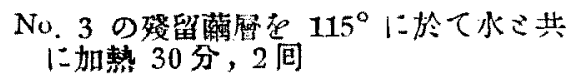 & 2.6 & 顯 滥 \\
\hline
\end{tabular}

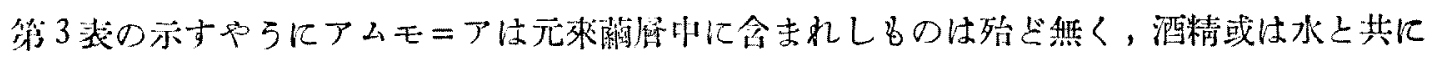

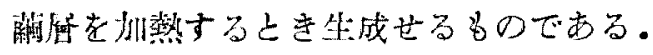

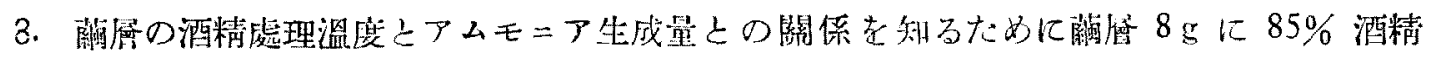

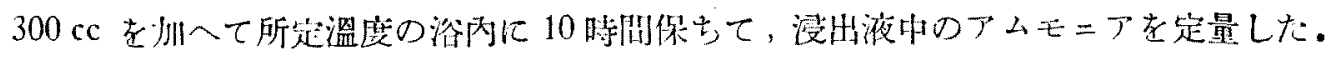

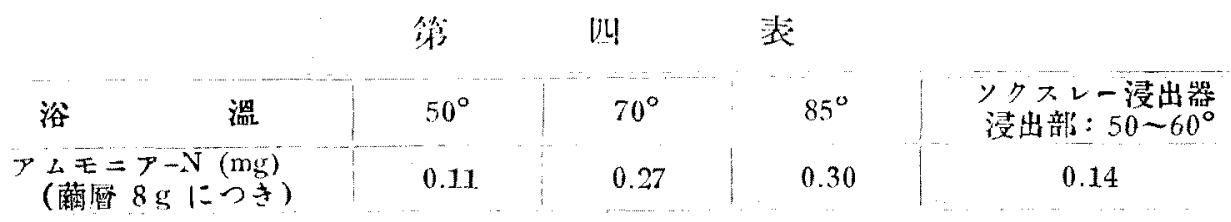

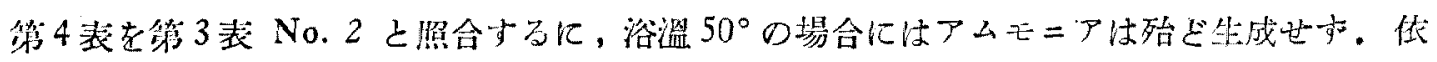

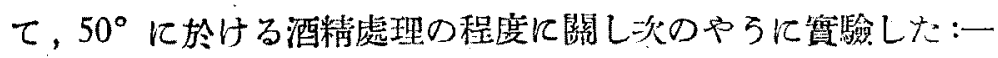

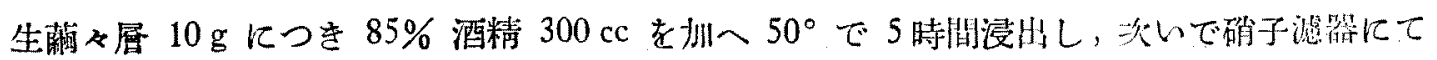




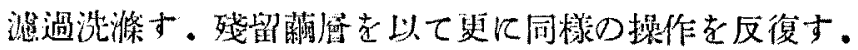

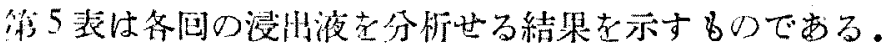

\begin{tabular}{|c|c|c|c|c|c|}
\hline 浸出㮌 次 & 第1间 & 第，2间 & 第3 回 & 第 4 问 & 計 \\
\hline 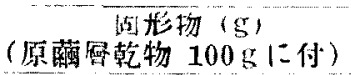 & 0.883 & 0.298 & 0.112 & 0.064 & $\begin{array}{c}1.357 \\
(\text { 内厕分 }=0.220)\end{array}$ \\
\hline
\end{tabular}

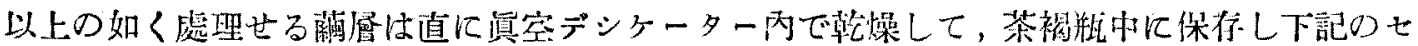

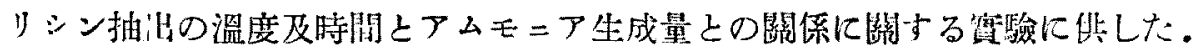

籍 1 胃

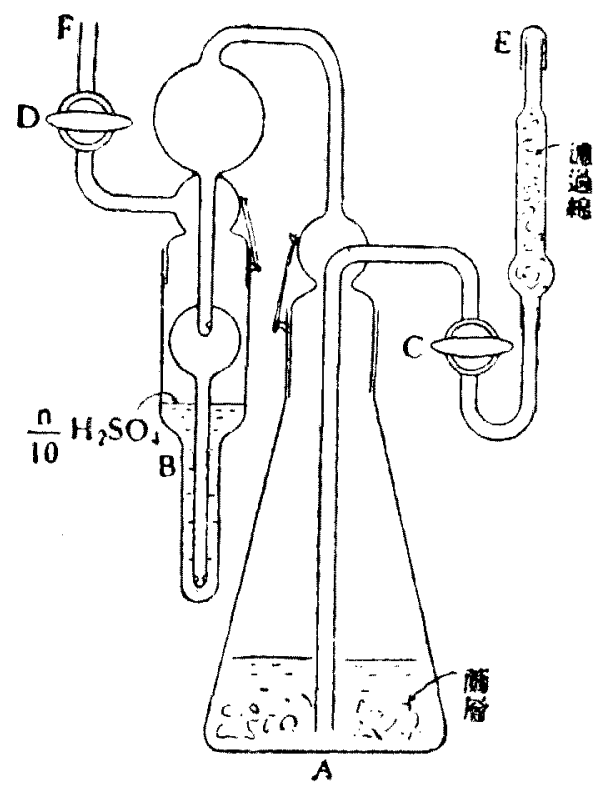

此望驗には第 1 圖に示せる裝盢を使用した。

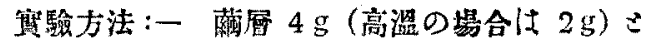

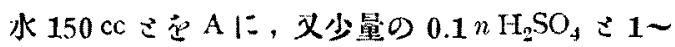

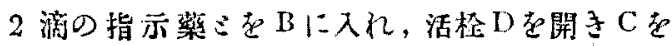
閉5て装置老所定より約 $20^{\circ}$ 低き浴に入れて加繁 $i ，$ 所定溫度に達してより所定時間走經過した時

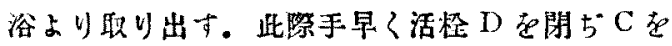

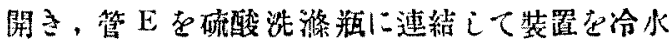

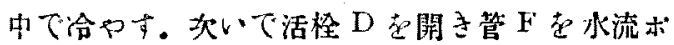

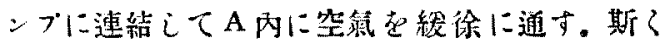
て加熱中生成さる遊離アムモニアを亩内の研酸中

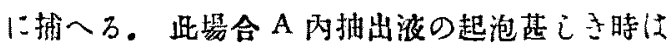
少量のブチルアルコールを加へてえを抑淤する。

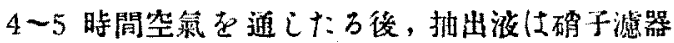
で滤し蔽絲法冾水で充分に担洗す万。抽出液中 のつムモニフ洁前瓝のやjにてて定量す万。

第6表セリシンの抽出化際し生成せるアムモ=アーN (mg)

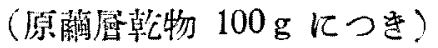

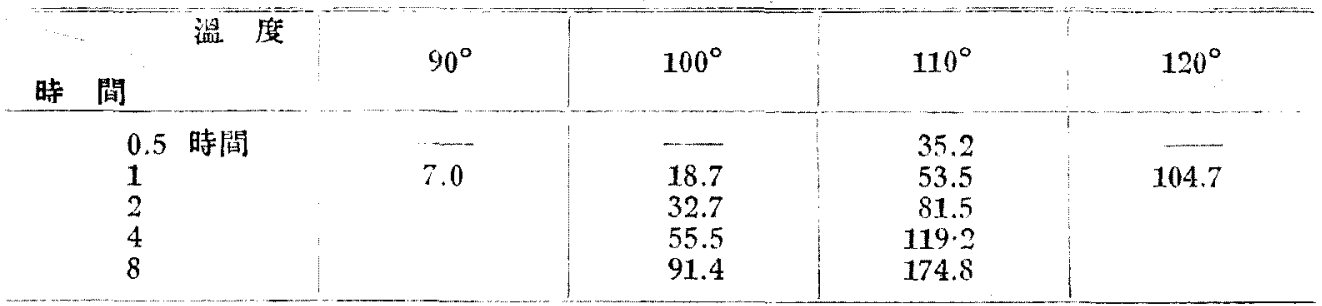

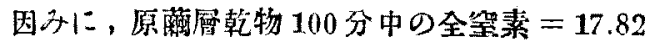

第6 表の示すゃうにアムモ二アの生成量は抽出溫度及時間之许行的に增加する。

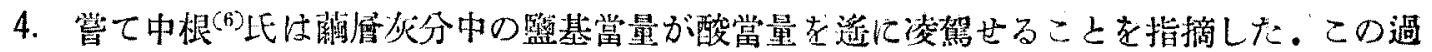
剩監基が上逃絹質分解の原因ならざるやを檢するを的次の苗驗を行つを：一 


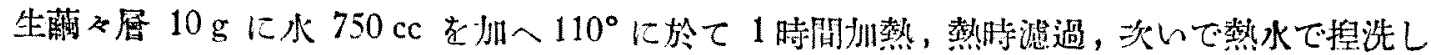
て得たる抽出液及殘泹（主にフイブロイン）を分析して第７表に示す結果を得た。

\begin{tabular}{|c|c|c|c|}
\hline \multirow{2}{*}{ 成 } & \multicolumn{3}{|c|}{ 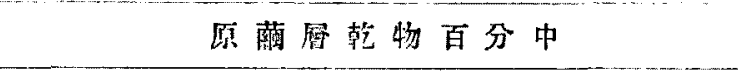 } \\
\hline & 抽出液 & 残 渣 & 計 \\
\hline $\begin{array}{l}\text { 余固形物 } \\
\text { 粗炏 分 } \\
\mathrm{SiO}_{2} \\
\mathrm{Al}_{2} \mathrm{O}_{3}+\mathrm{Fe}_{2} \mathrm{O}_{3} \\
\mathrm{CaO}\end{array}$ & $\begin{array}{l}23.10 \\
0.710 \\
0.019 \\
0.020 \\
0.268\end{array}$ & $\begin{array}{l}\overline{0.296} \\
0.016 \\
0.019 \\
0.155\end{array}$ & $\begin{array}{l}\overline{1.006} \\
0.035 \\
0.039 \\
0.423\end{array}$ \\
\hline
\end{tabular}

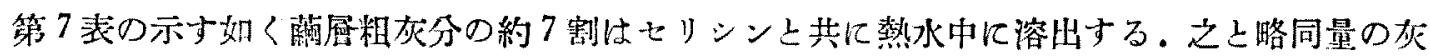

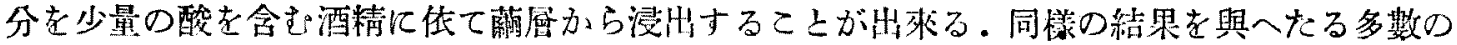

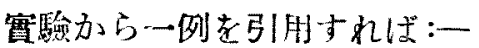

销居 $20 \mathrm{~g} \mathrm{~K} 0.02 n \mathrm{CH}_{3} \cdot \mathrm{CO}_{2} \mathrm{H}$ を含有せる $50 \%$ 酒精 $500 \mathrm{cc}$ を㧈へ 24 時間室溫に放置し，

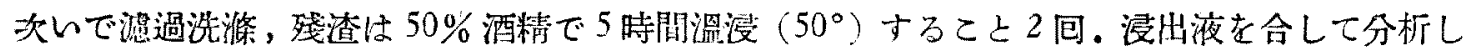
て次の結果を得た。

\section{第 8 表 $0.02 n \mathrm{CH}_{3} \cdot \mathrm{CO}_{2} \mathrm{H}$ 含有 $50 \%$ 酒精に依る抽出物 $(\mathrm{g})$} (原藏層乾物 $100 \mathrm{~g} \mathrm{几つ?)}$

\begin{tabular}{c|c|c|c|c|c|}
\hline 全淍形物 & 粗灰 分 & $\mathrm{SiO}_{2}$ & $\mathrm{Al}_{2} \mathrm{O}_{3}+\mathrm{Fe}_{2} \mathrm{O}_{3}$ & $\mathrm{CaO}$ & $\begin{array}{c}\text { 元 } \\
(\mathrm{mg})\end{array}$ \\
\hline 2.405 & 0.732 & 0.000 & 0.029 & 0.316 & 0.83 \\
\hline
\end{tabular}

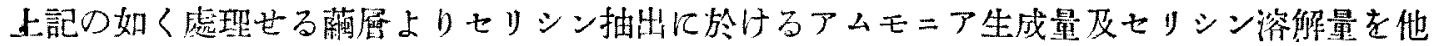

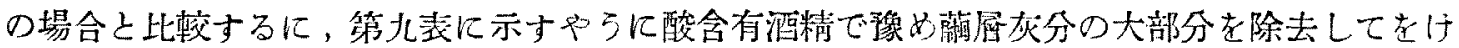

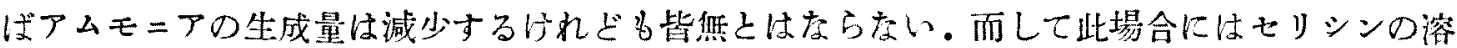
解量も多少減少し，且つ抽出液孝放冷すればセリシンの一部は凝固沈激するのが常であつた。

第9袁 37.5 倍量の水と共に $110^{\circ}$ に於て 1 時間加熱して藏愿より 抽出せらる」セリシン量とアムモニアの生成量

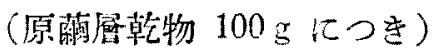

\begin{tabular}{|c|c|c|c|}
\hline No. & 落 暦 $の$ 前 處 理 & 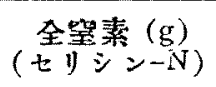 & 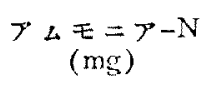 \\
\hline 1 & 原生䔵《辟 & 3.345 & 53.9 \\
\hline 2 & $85 \%$ 酒精に一温浸 $\left(50^{\circ}\right)$ & 3.321 & 53.5 \\
\hline 3 & 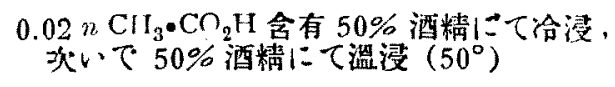 & 2.910 & 27.6 \\
\hline
\end{tabular}




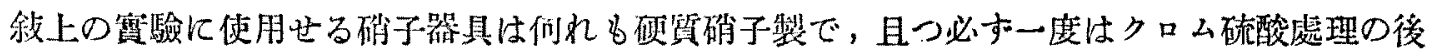
数時间蒸葻洗涤せるものではあるが，猶硝子より溶出することある可きアルカリが絹質分解の

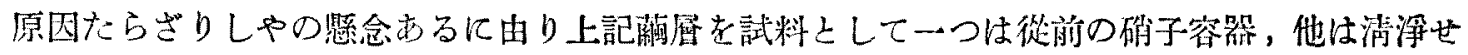

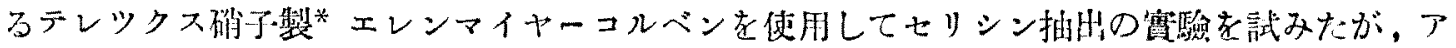
ムモニア生成量には何等の浩異を示さなかつた。

以上に據り絹筫の濕潤時加熱に依る分解の原因は恐らく絹絲蛋白質自體に包藏されをるもの であらう・

\section{總括}

（1）少量の多偩イオンの存在て於てはセリシンは酒精によつて完全て疑固される。

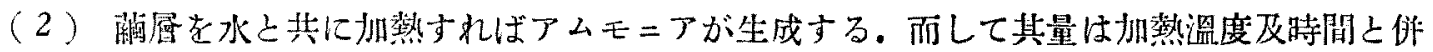
行的に增加与る.

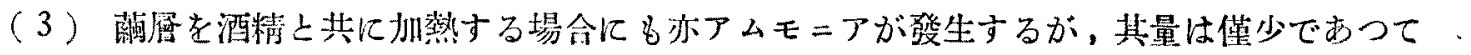
$50^{\circ}$ 前嵝の溫度では殆に゙皆無である。

本研究は日本學術振興會の御援助に依て行はれたものである。茲に深謝の意を表す。

\section{文㱆}

（1）金子英雄：製綵化學，76（東京，炤和 11)。

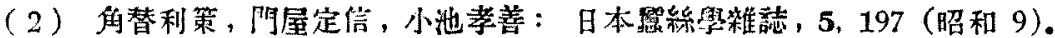

(3) H. H. Musher: Amer. Dyestuff Rept., XXI, 341 (1932).

(4) M. IIarris: Ibid. XXIII, 228 (1934).

(5) E. Abderhalden: Hindbuch d. Biolug. Arbeitsmethoden, Abt. I, Chem. Methoden, Teil. 7, S. 347 (Berlin, 1923).

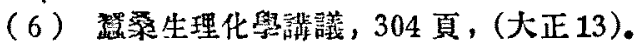

